\title{
Coastal and deep-sea benthic diversities compared
}

\author{
J. S. Gray ${ }^{1 *}$, Gary C. B. Poore ${ }^{2}$, K. I. Ugland ${ }^{1}$, Robin S. Wilson ${ }^{2}$, F. Olsgard ${ }^{1}$, \\ Ø. Johannessen ${ }^{1}$
}

'Biologisk Institutt, Universitetet i Oslo, Pb 1064 Blindern, N-0316 Oslo, Norway
${ }^{2}$ Museum of Victoria, 71 Victoria Crescent, Abbotsford, Victoria 3067, Australia

\begin{abstract}
Most generalisations about marine benthic diversity (species richness) are derived from few studies, few samples and low species numbers. It is questionable whether the data on which most paradigms, especially about the deep sea, are based truly represent general patterns of marine diversity. Available information from deep-sea studies are summarised and compared with some extensive data sets from the shallow coasts of Norway and Australia. We show that species richness per unit area is as high, if not higher in shallow sedimentary habitats as was reported for the deep-sea data by Grassle \& Maciolek (1992; Am Nat 139:313-341). Apparent high diversity in the deep sea may be explained, in part, by the vast area of this environment. All surveys in both the deep-sea and coastal habitats are shown to traverse a variety of microhabitats and thus sediment heterogeneity is not an explanation for the high species richness in coastal environments.
\end{abstract}

KEY WORDS: Species richness Diversity - Benthos - Deep sea Shelf

\section{INTRODUCTION}

There are 3 generally accepted gradients of diversity in the sea. These have been summarised by Levinton (1995) as: firstly, "The best-known diversity gradient is an increase of species diversity from high to low latitudes in continental shelf benthos, in the plankton in continental shelf regions and in the open ocean'; secondly, 'in both benthic and water column assemblages, the open sea tends to have more species than do inshore habitats' and thirdly, '...there is a regular change in benthic diversity from coast to abyssal plain. Species diversity of macroinvertebrates and fishes increases with depth, to a maximum just seaward of the continental rise, and then decreases with increasing distance towards the abyssal plain'. These paradigms were based initially on samples collected with a semi-quantitative anchor-dredge along a transect from Gayhead, USA, to Bermuda (Hessler \& Sanders 1967) and from a variety of different habitats from the boreal areas to the tropics and from estuaries to the deep-sea

•E-mail: j.s.gray@bio.uio.no slope (Sanders 1968). Using rarefaction curves, it was shown that the highest number of species was found in tropical shallow areas, followed by the deep-sea slope, with tropical estuaries having lower diversity and boreal estuaries the lowest (Sanders 1968). Following these pioneering studies others have confirmed that coastal diversity is low compared with deep-sea and offshore habitats, (Sanders 1969, Dayton \& Hessler 1972, Rex 1973, Grassle 1991, Gage \& Tyler 1992, Huston 1994)

Recently samples of deep-sea sediments from depths between 1500 and $2100 \mathrm{~m}$ off the east coast of North America were analysed and a total of 798 species was found from $21 \mathrm{~m}^{2}$ of sediment (Grassle \& Maciolek 1992). These results were claimed to 'indicate a much greater diversity of species in the deep sea than previously thought' and to show that 'In contrast to the deep sea, shallow water marine communities outside of tropical areas have relatively few species'.

This claim has been repeated in other modern textbooks besides Levinton's (1995) cited above. For example, Begon et al. (1996, p. 905) state 'species richness of benthic invertebrates... has a peak richness at $2000 \mathrm{~m}$ ' and Huston (1994, p. 358) states 'most groups of organ- 
isms apparently reach their maximum diversity at depths below the continental slope'.

In contrast Gray (1994) and Coleman et al. (1997) suggest that species richness on a transect along the Norwegian continental shelf and in an area in southern Australia is as high as that of the deep sea as reported by Grassle \& Maciolek (1992). In reponse to Gray's paper, Gage (1996, p. 267) claimed that 'there are many other data sets published in the 1970s from pristine shallow water areas... where species richness is much higher than coastal sediments off New England', the locality of Sanders' (1968) original study. He added that Sanders himself found that coastal data from Friday Harbor, San Juan Islands on the US west coast had species richness as high as that of the continental slope (Sanders 1969). Yet Gage cited only 2 papers (Pearson 1970. Gage 1973) to document his argument, both from from the west coast of Scotland, and neither paper contained data on cumulative species:area relationships. Recently, however, Gage (1996) has combined data from the 1973 study to give a species:area curve showing ca 300 species from $11 \mathrm{~m}^{2}$. a high figure compared to Sanders' $(1968,1969)$ data but below the 600 species reported by Gray (1994) and 800 species reported by Coleman et al. (1997). We believe therefore that, despite Gage's claim, there are few published data sets specifically on species:area relationships in coastal areas which can be compared with deep-sea data. Thus we contend that more data sets are urgently needed in order to answer the question: Can species richness be equally high in comparable areas of coast and deep sea?

One of the central patterns in biodiversity, noted universally, is that the number of species increases with area sampled (Williamson 1981, Rosenzweig 1995). These species:area curves have often been used to compare species richness between areas, for example a comparison of species richness of neotropical landbirds in different biomes, lowland, subtropical, temperate and puna (Rathbek, cited in Rosenzweig 1995). If one area has a higher species richness per unit area than another, then one can ask whether or not this is due to this area having a higher number of individuals, or alternatively a higher number of habitats, or to it containing more biogeographical provinces per unit area (Rosenzweig 1995, p. 190).

We have 4 coastal data sets which afford a better comparison than data previously published since they are from limited areas [within a few $\mathrm{km}$ rather than the transects of $178 \mathrm{~km}$ studied by Grassle \& Maciolek (1992) and $1200 \mathrm{~km}$ studied by Gray (1994)] and from opposite ends of the earth, Australia and Norway. Our data are used to answer the question: Do comparable areas of coast and deep sea have similar species richness?

\section{MATERIAL AND METHODS}

We first review the available published data on which most paradigms about deep-sea species richness are based and present them in tabular form.

The first of our 4 coastal data sets were taken in Norway as part of routine monitoring of the effects of the oil industry and mining on the seabed. The organisms were sampled by means of a Van Veen grab $\left(0.1 \mathrm{~m}^{2}\right)$ with 5 replicates taken per station and the animals retained on a $1 \mathrm{~mm}$ sieve were identified to the lowest practical taxonomic level. Only the data for stations unaffected by oil activities are used. The data are taken from small geographical areas. At the Frigg oilfield 5 sets of samples were taken within an area of ca $25 \mathrm{~km}$ radius $\left(2^{\circ} 01^{\prime}\right.$ to $2^{\circ} 33^{\prime} \mathrm{E}, 59^{\circ} 34^{\prime}$ to $60^{\circ} 05^{\prime} \mathrm{N}$ ) with uniform depth ( 110 to $118 \mathrm{~m}$ ), and from a uniform habitat of fine sand.

The second data set is from Jøssingfjord in southern Norway $\left(58^{\circ} 17^{\prime} \mathrm{N}, 6^{\circ} 10^{\prime} \mathrm{E}\right)$ and from within an area of $6 \times 3 \mathrm{~km}$. The stations were all undisturbed and are numbers 53, 55, 58 and 61 from Olsgard (1993) and Olsgard \& Hasle (1993), within a depth range of 107 to $185 \mathrm{~m}$ and with a sediment median particle diameter ranging from 2.9 to 3.1 phi with a silt clay content between 20.6 and $33.4 \%$. Van Veen grab samples of $0.1 \mathrm{~m}^{2}$ were taken and animals retained on a $1 \mathrm{~mm}$ sieve were identified to the lowest taxonomic level.

The third and fourth data sets come from the southeastern coast of Australia. The third is from a broadscale survey of Port Phillip Bay (Poore et al. 1975, R. S. Wilson, S. Heislers \& G. C. B. Poore unpubl.), a largely enclosed marine bay of $1908 \mathrm{~km}^{2}\left(37^{\circ} 53^{\prime}\right.$ to $38^{\circ} 21^{\prime} \mathrm{E}$. $144^{\circ} 23^{\prime}$ to $145^{\circ} 07^{\prime} \mathrm{S}$ ) with little freshwater influence. Sediments are coarse sand at depths shallower than $10 \mathrm{~m}$ and fine mud down to the maximum depth of $23 \mathrm{~m}$. Smith-McIntyre grab samples of $0.1 \mathrm{~m}^{2}$ were taken at 86 stations, 5 replicates at each, throughout the bay between 1969 and 1973. All taxa retained on a $1 \mathrm{~mm}$ mesh were identified to species level using the best possible available taxonomy. Even today about half remain undescribed, but were determined as putative species. We present data for the sand and mud stations combined and for the separate sediments. The fourth set comes from a coastal setting (Coleman et al. 1997). Coarse sand sediments in eastern Bass Strait at depths between 11 and $51 \mathrm{~m}$ were sampled with 104 Smith-McIntyre grab samples of $0.1 \mathrm{~m}^{2}$ over a $50 \mathrm{~km}$ distance along the coast $\left(37^{\circ} 49^{\prime}\right.$ to $38^{\circ} 04^{\prime} \mathrm{E}$, $148^{\circ} 00^{\prime}$ to $148^{\circ} 44^{\prime} \mathrm{S}$ j. Species retained on a $0.5 \mathrm{~mm}$ mesh were retained and identified.

All studies excluded sessile invertebrates and typically meiofaunal taxa such as nematodes. Poore et al. (1975) tabulated all the data and summarised it for Port Phillip Bay but no species:area relationships have been 
calculated. Relationships between species and number of individuals and between species and area for limited numbers of samples in Bass Strait were presented by Coleman et al. (1997) but not for all samples taken. The new analyses presented here are of the original species:station matrices. Cumulative mean species number and standard deviations were calculated using sets of 100 randomised samples for sample areas of minimum size (individual grab samples) and then sample area was increased by pooling areas until the total area sampled at each site was reached.

\section{RESULTS}

\section{Critical summary of deep-sea benthic species data}

It is generally claimed (Rex 1973, Gage \& Tyler 1992, Grassle \& Maciolek 1992, Levinton 1995) that Hessler \& Sanders (1967) were the first to show high deep-sea diversity. All the above authors have overlooked a paper by Sars (1872) in which he reported 427 species at depths between 400 and $600 \mathrm{~m}$ off the Lofoten Islands, Norway. Thus, it has been known for over a century that many species occur at depths down to $600 \mathrm{~m}$.

Closer examination of recent data (Table 1) shows that the number of species and areas on which generalisations about patterns of marine diversity have been made are taxonomically limited and in most cases surprisingly low. Sanders $(1968,1969)$ only dealt with the polychaete-bivalve fraction of the fauna. Rex (1973) dealt with only gastropods, Rex et al. (1993) with gastropods, bivalves and isopods, and Poore et al. (1994) with only isopods. The only exceptions are the studies of Etter \& Grassle (1992), who studied the distributions of 1597 species, and Grassle \& Maciolek (1992), who studied all species that could be reliably determined.

From the data presented in Table 1 it is understandable that great interest was given to the high species richness recorded by Grassle \& Maciolek (1992), which far exceeds that of previous deep-sea studies. Yet the remaining data are surprisingly poor in species. Sanders' (1968) data, on the basis of which the ideas of low coastal to high deep-sea and high tropical to low temperate diversity gradients were first developed, comprise a remarkably low number of species, having a maximum of 95. Sanders' (1969) data from Friday Harbor, which Gage (1996) stated shows high coastal diversity, report a maximum of 80 species from 2000 individuals for the polychaete-bivalve fraction of the fauna. This is comparable to that of Sanders (1968) for the continental slope. Similarly Rex's (1973) data, on which the pattern of low coastal and abyssal diversity and a maximum diversity at depths of 2000 to $3000 \mathrm{~m}$ were first based, have extremely low numbers of species. Likewise Rex et al.'s (1993) study of latitudinal gradients of deep-sea diversity is based on only 100 species. Only Grassle \& Maciolek's (1992) transect at 1500 to $2100 \mathrm{~m}$ depth and Etter \& Grassle's (1992) study of the influence of sediment particle size on the deep-sea diversity have numbers appropriate to analyse broad-scale patterns of biodiversity. Etter \& Grassle's (1992) study is not an ecological sample of a given area but a compilation of data from the whole of the N. Atlantic and thus is not comparable.

\section{Data from the coasts of Norway and Australia}

Total numbers of species and individuals, area sampled and depth range are presented (Table 2). Fig. 1 plots the cumulative number of species against area for the Norwegian and Australian coasts as means $( \pm \mathrm{SD}$ ) for 100 randomised samples of each sample size (e.g. 0.5, $1.0 \mathrm{~m}^{2}$, etc.). We are not able to explain the greater variability of the Australian data compared with the Norwegian data.

Table 2 and Fig. 1 show that for similar areas of sea bed coastal habitats of Norway and Australia are as rich in species as the habitat in Grassle \& Maciolek (1992), the only comparable deep-sea study. Grassle \&

Table 1. Numbers of species and individuals, depth and area used to make generalisations about deep-sea diversity patterns

\begin{tabular}{|lcccc|}
\hline Source & No. of species & No. of individuals & Area sampled $\left(\mathrm{m}^{2}\right)$ & Depth $(\mathrm{m})$ \\
\hline Hessler \& Sanders (1967) & $196-365$ & $3737-25242$ & $?$ & $1330-4680$ \\
Sanders (1968) & $10-95$ & $276-9716$ & $?$ & $300-2500$ \\
Sanders (1969) & 80 & 2000 & $?$ & $15-92$ \\
Rex (1973) & 136 & 9034 & $?$ & $70-4970$ \\
Hessler \& Jumars (1974) & 108 & 9648 & 2.5 & $5500-5800$ \\
Grassle \& Maciolek (1992) & 798 & 272009 & $1300-2100$ \\
Etter \& Grassle (1992) & 1597 & 214508 & $250-3029$ \\
Rex et al. (1993) & ca 100 & 6870 & $?$ & $500-4000$ \\
Poore et al. (1994) & 359 & & $?$ & $200-3150$ \\
\end{tabular}



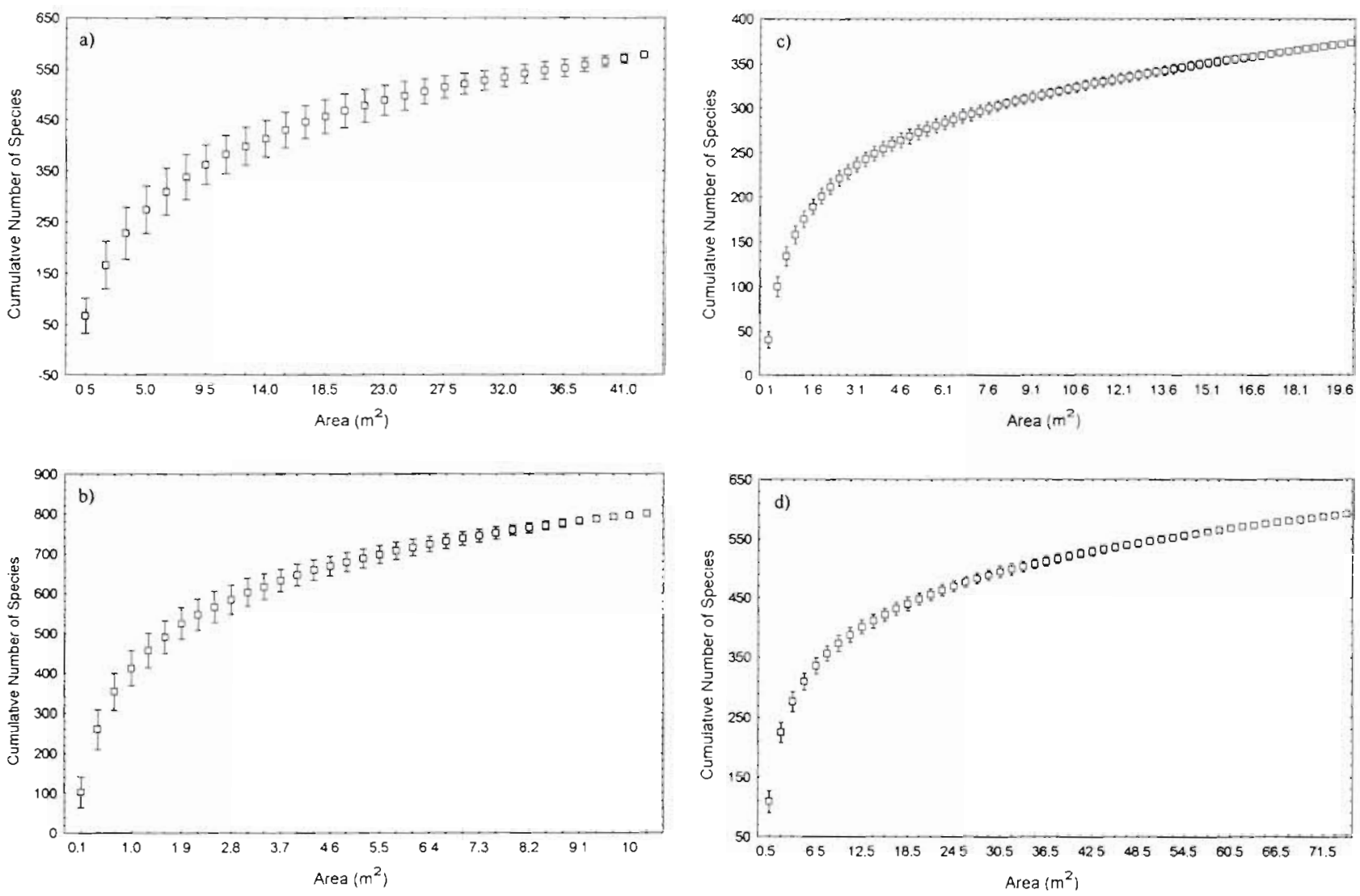

Fig. 1. Mean cumulative number of species against area with 100 randomised samples for each sample area size. (a) Port Phillip Bay, Australia; (b) Bass Strait, Australia; (c) Jossingfjord, Norwegian coast; (d) Frigg area, Norwegian shelf. Error bars are SD

Maciolek (1992) reported 698 species from 90000 individuals in $21 \mathrm{~m}^{2}$, whereas the Bass Strait data, the most rich of our 4 , shows 803 species from 60258 individuals in $10.2 \mathrm{~m}^{2}$. Other surveys support high number of species in coastal regions: 572 species in $12.3 \mathrm{~m}^{2}$ in Western Port, Australia (Coleman et al. 1978), and 620 species in $50 \mathrm{~m}^{2}$ and 40000 individuals on the Norwegian shelf at 70 to $305 \mathrm{~m}$ depth (Gray 1994).

\section{DISCUSSION}

It is clear from the analyses presented here (Fig. 1, Tables 1 \& 2) that species richness per unit area in deep sea and coastal environments is of the same order of magnitude and neither can be said to be consistently higher than the other. Criticisms of this stance cannot be based on the adequacy of the data (in neither habi-

Table 2. Species numbers in some coastal sediments

\begin{tabular}{|c|c|c|c|c|c|}
\hline Region & $\begin{array}{c}\text { No of } \\
\text { species }\end{array}$ & $\begin{array}{c}\text { No. of } \\
\text { individuals }\end{array}$ & $\begin{array}{l}\text { Area } \\
\left(\mathrm{m}^{2}\right)\end{array}$ & $\begin{array}{l}\text { Depth } \\
(\mathrm{m})\end{array}$ & Source \\
\hline Jossingfjord, Norwegian coast & 358 & 38569 & 7.2 & $107-185$ & This paper \\
\hline Frigg, Norwegian shelf & 592 & 290401 & 75 & 70 & This paper \\
\hline Port Phillip Bay, Australia & 580 & 156274 & 43 & $2-23$ & This paper \\
\hline Port Phillip Bay, sand & 542 & 49582 & 15 & $2-10$ & This paper \\
\hline Port Phillip Bay, mud & 303 & 93173 & 27.5 & $9-23$ & This paper \\
\hline Bass Strait, Australia & 803 & 60258 & 10.4 & $11-51$ & This paper \\
\hline Lochs Linnhe \& Eil, Scotland & 323 & 13014 & 12 & $9-111$ & Pearson $(1970)$ \\
\hline Firth of Lorne, Loch Etive, Loch Creran, Scotland & ca 300 & $\mathrm{ca} 37000$ & 11 & $24-117$ & Gage (1973) \\
\hline Irish Sea & $326^{\mathrm{a}}$ & 36607 & 11.4 & $7-130$ & Mackie et al. (1997) \\
\hline
\end{tabular}


tat are many sample series available). Of more consequence is the depth range sampled. All our shelf sample sets come from a narrow depth range, $60 \mathrm{~m}$ maximum while the comparable deep-sea sets are usually from depth ranges of $600 \mathrm{~m}$ and usually $>2000 \mathrm{~m}$.

We first examine species:area relationships. Abele \& Walters (1979) reanalysed Sanders (1968) data and showed convincingly that over all the data sets obtained by Sanders (1968) species richness increased in proportion to the area sampled and concluded that the deep sea is not extraordinarily species rich and that estuaries are not depauperate in these terms. Their conclusions seem not to be generally known or accepted. Our data support this hypothesis since comparable areas of coastal sediments have similar species numbers to the deep-sea sediments studied by Grassle \& Maciolek (1992). Not all areas of either the coast or the deep sea have high diversity. It is well known that coastal areas with high physical variability such as estuaries have low diversity. Similarly Jumars (1976) showed low species numbers in the deep sea Santa Catalina Basin, off the coast of California, as did Blake \& Hilbig (1994) for depths between 530 and $2003 \mathrm{~m}$ off the eastern USA. The Norwegian Sea at depths of $4000 \mathrm{~m}$ is known to have low diversity (Rex et al. 1993). Olsgard \& Gray (1995) have reviewed a large number of data sets from the North Sea that are subjected to effects of oil and gas exploration and show species richness somewhat lower than those illustrated here but higher than all those from the deep-sea studies in Table 1, except that of Grassle \& Maciolek (1992). It is likely that there is a considerable range in species:area relationships in both coastal and deep sea areas. More data sets, especially from tropical areas, are urgently needed.

Given that areas of high species richness in coastal and deep sea areas have similar species:area relationships, is there any evidence that coastal and deep sea areas differ in species:individual relationships? Fig. 2 plots the number of species against number of individuals for estuarine (E), coastal (C) and deep sea (D) data sets. The outlying data set of Etter \& Grassle (1992) (1597 species from 272009 individuals) differs from the others in that it is data compiled from the whole of the North Atlantic and not from a restricted geographical area. The most detailed set from a restricted area of the deep sea (Grassle \& Maciolek 1992) has approximately the same species:individuals ratio as coastal data. On the evidence available there is no difference between species:individual relationships between species-rich areas of coast and deep sea. An interesting observation is that there appears to be an increase in species number with number of individuals up to an asymptote at around 800 species, but this suggestion is based on relatively few data sets

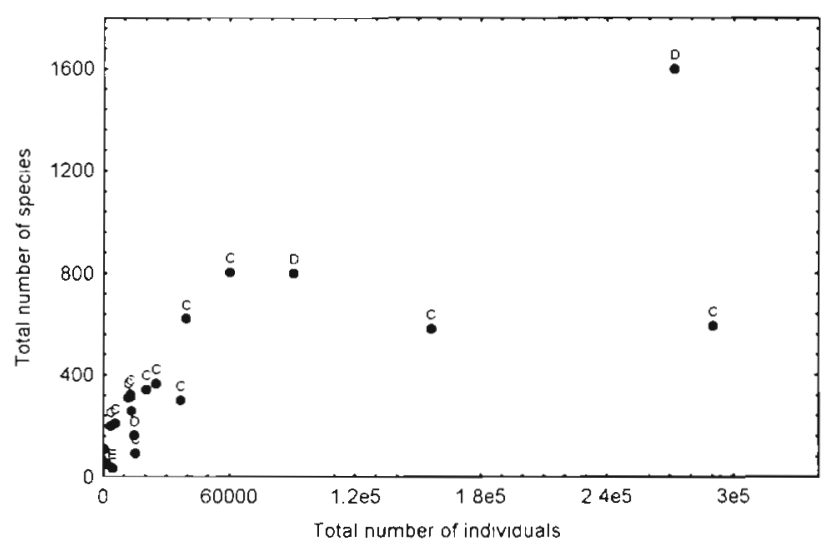

Fig. 2. Number of species against number of individuals for estuarine (E), coastal (C) and deep-sea (D) data sets in Tables 1 \& 2

and is probably limited by the geographical extent of the surveys selected. The numbers of species present are much higher on wider scales.

Another often raised criticism of comparing coastal data with the deep sea (e.g. Gage 1996 and referees of this paper) is that one is not comparing like with like since the coastal data are from a variety of habitats whereas the deep sea data are from one single habitat. This argument states that deep-sea sediments comprise only one habitat, soft muddy sediment, whereas the coast has more habitats. Gage (1996) even goes so far as to suggest that one cannot compare shelf and deep-sea data since one is comparing within-habitat $(\alpha)$ diversity (the homogeneous sediments of the deep-sea) with between-habitat $(\beta)$ diversity (the heterogeneous sediments of the coastal area). This we believe is a fallacious argument since it is possible to compare species:area relationships without having to consider habitat. (For example, one can ask whether a tropical rain forest has higher species richness per unit area than a boreal deciduous forest.) We are further surprised that critics of our attempts to compare coastal and deep-sea benthic communities claim that Sanders (1968) original paper is a withinhabitat comparison. Again, this argument was carefully analysed by Abele \& Walters (1979, their Table 2, p. 118), who showed that Sanders' (1968) data covered sediments ranging from 22 to $86.3 \%$ silt and from 6.5 to $35 \%$ clay with organic content varying from 0.33 to $6.7 \%$ organic carbon. Clearly Sanders' (1968) original data on which the paradigms of marine biodiversity were erected are not from a uniform habitat, as claimed, but from different sedimentary habitats.

We do not deny that the coastal data are from a variety of habitats. Port Phillip Bay samples came from 2 quite different sediment types, predominately mud 
and predominately sand. Nevertheless, the numbers of species taken from just 1 of these sediment types (Table 2) are still large, $93 \%$ of the total for the whole bay in the case of sand. Furthermore, as many as 197 species could be taken from a single set of 5 simultaneously taken samples from 1 sandy station, an area of $0.5 \mathrm{~m}^{2}$ (Poore et al. 1975). Mean sediment grain size ranged from 0.3 to $0.9 \mathrm{~mm}$ in the Bass Strait samples, so they were remarkably uniform. There, one $0.1 \mathrm{~m}^{2}$ sample comprised 187 species and 12 out of 38 samples taken on 1 occasion comprised more than 100 species (Coleman et al. 1997). Furthermore it has been overlooked that the deep-sea data of Grassle \& Maciolek. (1992) are not from a single habitat. In arguing that Gray's (1994) data were from many habitats, Gage (1996) argued 'hence the clear step-like increases in accumulated species from samples ordered along a linear north-south gradient ... which may reflect not only previously unencountered species associated with the differing sediment facies, but possibly also the geographical limits in range of individual species.' This is undoubtedly true. However, examination of Grassle \& Maciolek's paper (1992, their Fig. 11, p. 329) shows that these data show exactly comparable step-like increases when a new sample site was incorporated along the transect. Grassle \& Maciolek (1992) acknowledged this by stating (p. 313) 'Deep-sea microhabitats tend to persist longer, be smaller in spatial extent, and be separated by longer distances between patches in comparison with the most closely studied shallow-water marine communities.' The relative scales of micro-habitats and habitats were not defined but along a $176 \mathrm{~km}$ transect there must be considerable habitat variation of the type described by Grassle \& Maciolek (1992). Variation in habitat structure at small-scales is known to influence deep-sea fauna (Jumars 1976, Grassle \& Morse-Porteus 1987, Grassle et al. 1990). Thus both Grassle \& Maciolek's (1992) and our data are clearly studies of between-habitat $(\beta)$ diversity.

We conclude that on the basis of the data currently available similar areas of the coast and deep sea contain similar numbers of species and that there are similar species:individuals relationships and species:habitat relationships in both coastal and deep sea. The scales of the habitat patchiness may be smaller in the deep sea as noted by Grassle \& Maciolok (1992) but the fauna is comparably smaller also. Since species:area, species:individual and species:habitat patterns are comparable in coastal areas and the deep sea there are no needs for complex explanations of the reasons for differences between the two [see Gage \& Tyler (1992) for a coverage of the theories explaining the purported coast:deep-sea diversity gradient].
Warwick \& Clarke (1996) raised another issue claiming that in benthic sediment assemblages there are more species of intermediate-sized organisms than larger or smaller. Based on analyses of some benthic communities, but largely on one area the Bay of Morlaix, they suggested that smaller organisms will comprise fewer species per 100 individuals than larger organisms. Following this line of reasoning, which we have no reason to doubt, samples retained on a $1 \mathrm{~mm}$ sieve should have more species per 100 individuals than samples retained on a finer sieve (as well as the more obvious greater species per unit area). We are not convinced that different mesh sizes are totally responsible since our data from southern Australia are contradictory. The greatest species:individual ratio of the 4 shelf sites for which we present data is in Bass Strait. Here, samples were seived on $0.5 \mathrm{~mm}$, while $1 \mathrm{~mm}$ was used elsewhere, but produced the most species and third lowest number of individuals. Table 2 highlights the differences. This observation indicates how difficult it is to make generalisations from few samples.

An important argument for future research agendas is that coastal habitats at landscape scales are far more varied than the deep sea with estuaries, coastal sand and mud flats, rocky shores, seagrass beds, kelp forests, mangroves and coral reefs. Thus it is intuitive (because many species are restricted to 1 or a few of these habitats) that overall coastal biological diversity must be higher than that of the deep sea floor. Here we have shown that in 1 of these habitats alone species richness can be higher in coastal areas than in the 1 data set available for the deep sea.

The current distribution of diversity could theoretically be related to local ecological factors and processes (e.g. disturbance), but studies of such processes cannot be used to explain large-scale patterns. This is because factors responsible for creating an assemblage of species may be different from those maintaining that diversity, and ecological hypotheses are thus untestable over large spatial scales. Phylogenetic data, hypotheses about the evolutionary history of organisms, are more tractable areas of study since they integrate ecological outcomes (the ultimate fates of populations over large temporal scales) into evolutionary trees. These phylogenies are testable hypotheses, and once accepted as robust representations of the evolutionary history of a group of organisms they can be used to investigate historical relationships between faunas of different regions. Data of this type are sorely needed for marine benthic invertebrates.

Acknowledgement. We thank Noel Coleman for allowing us to use the Bass Strait data in this analysis. 


\section{LITERATURE CITED}

Abele LG, Walters K (1979) Marine benthic diversity: a critique and alternative explanation. J Biogeogr 6:115-126

Begon M, Harper JL, Townsend CR (1996) Ecology: individuals, populations and communities, 3rd edn. Blackwell Scientific Publications, Oxford

Blake JA, Hilbig B (1994) Dense infaunal assemblages on the continental slope off Cape Hatteras, North Carolina. Deep Sea Res 41:875-899

Coleman NC, Cuff W, Drummond M, Kudenov JD (1978) A quantitative survey of the macrobenthos of Western Port, Victoria. Aust J Mar Freshwat Res 29:445-466

Coleman N, Gason A, Poore GCB (1997) High species richness in the shallow marine waters of south-east Australia. Mar Ecol Prog Ser 154:17-26

Dayton PK, Hessler RR (1972) Role of biological disturbance in maintaining diversity in the deep sea. Deep Sea Res 19: $199-208$

Etter RJ, Grassle JF (1992) Patterns of species diversity in the deep-sea as a function of sediment particle size. Nature $360: 576-578$

Gage JD (1973) Community structre of the benthos in Scottish sealochs. I. Introduction and species diversity. Mar Biol 14 281-297

Gage JD (1996) Why are there so many species in deep-sea sediments? J Exp Mar Biol Ecol 200:257-286

Gage JD, Tyler PK (1992. Deep-sea biology: a natural history of organisms at the deep sea floor. Cambridge University Press, Cambridge

Grassle JF (1991) Deep-sea benthic biodiversity. Bioscience 41:464-469

Grassle JF, Maciolek NJ (1992) Deep-sea species richness: regional and local diversity estimates from quantitative bottom samples. Am Nat 139:313-341

Grassle JF, Maciolek NJ, Blake J (1990) Are deep-sea communities resilient? In: Woodwell GM (ed) The Earth in transition: patterns and processes of biotic impoverishment. Cambridge University Press, New York, p 359-384

Grassle JF, Morse-Porteus LS (1987) Macrofaunal colonization of disturbed deep-sea environments and the structure of deep-sea benthic communities. Deep Sea Res 20: $643-659$

Gray JS (1994) Is the deep sea really so diverse? Species diversity from the Norwegian continental shelf. Mar Ecol Prog Ser 112:205--209

Hessler RR, Jumars PA (1974) Abyssal community analysis from replicate box cores in the Central North Pacific. Deep Sea Res 14:65-78

Hessler RR, Sanders HL (1967) Faunal diversity in the deep sea. Deep Sea Res 14:65-78

Huston M (1994) Biological diversity: the coexistence of spe-

Editorial responsibility: Otto Kinne (Editor),

Oldendorf/Luhe, Germany cies in changing landscapes. Cambridge University Press. Cambridge

Jumars PA (1976) Deep-sea species diversity: does it have a characteristic scale? J Mar Res 25:217-246

Levinton JS (1995) Marine biology. Function, biodiversity, ecology. Oxford University Press, New York

Mackie ASY, Parmiter C. Tong LKY (1997) Distribution and diversity of Polychaeta in the southern Irish Sea. Bull Mar Sci 60:467-481

Olsgard F (1993) Do toxic algal blooms affect subtidal softbottom communities? Mar Ecol Prog Ser 102:269-286

Olsgard F, Hasle JR (1993) Impact of waste from titanium mining on benthic fauna. J Exp Mar Biol Ecol 172:185-213

Olsgard F, Gray JS (1995) A comprehensive analysis of the effects of offshore oil and gas exploration and production on the benthic communites of the Norwegian continental shelf. Mar Ecol Prog Ser 122:277-306

Pearson TH (1970) The benthic ecology of Loch Linnhe and Loch Eil, a sea-loch system on the west coast of Scotland. I. The physical environment and the distribution of the macrobenthoc fauna. J Exp Mar Biol Ecol 5:1-34

Poore GCB, Just J, Cohen BF (1994) Composition and diversity of Crustacea Isopoda of the southeastern Australian continental slope. Deep Sea Res 41:677-693

Poore GCB, Rainer, SF, Spies, RB, Ward E (1975) The zoobenthos program in Port Phillip Bay, 1969-73. Fish Wildl Pap Vic $7: 1-78$

Rex MA (1973) Deep-sea species diversity: decreased gastropod diversity at abyssal depths. Science 181:1051-1053

Rex MA, Stuart CT, Hessler RR, Allen JA, Sanders HL, Wilson GDF (1993) Global-scale patterns of species diversity in the deep-sea benthos. Nature 365:636-639

Rosenzweig ML (1995) Species diversity in space and time. Cambridge University Press, Cambridge

Sanders HL (1968) Marine benthic diversity: a comparative study. Am Nat 102:243-282

Sanders HL (1969) Benthic marine diversity and the stabilitytime hypothesis. In: Woodwell GM, Smith HH (eds) Diversity and stability in ecological systems. Brookhaven Symposium No. 22, Biology Department, Brookhaven National Laboratory, Upton, NY, p 71-81

Sars GO (1872) On some remarkable forms of animal life from the great depths off the Norwegian coast. 1. Partly from posthumous manuscripts of the late professor dr. Michael Sars. University program for the 1st half-year 1869. Brørger \& Christie, Christiania (Oslo)

Warwick RM ${ }_{1}$ Clarke KR (1996) Relationships between bodysize, species abundance and diversity in marine benthic assemblages: facts or artefacts? J Exp Mar Biol Ecol 202: $63-71$

Williamson MI (1981) Island populations. Oxford University Press, Oxford

Submitted: July 10, 1997; Accepted: October 8, 1997

Proofs received from author(s): November 21, 1997 